\title{
Peeling the paradigm: Exploring the professionalization of policing in Canada
}

\author{
Kelly W. Sundberg, ${ }^{\star}$ Christina Witt, ${ }^{\dagger}$ Graham Abela, ${ }^{\ddagger}$ and Lauren M. Mitchell
}

\begin{abstract}
Maintaining public trust, legitimacy, and credibility in a constantly evolving society has proven challenging for police in the 21st century. Rising public concerns regarding police accountability are driving the need to advance the paradigm of policing by reassessing the organizational structure of law enforcement in Canada. Supported by research identifying primary directives for maintaining public trust, this proposal argues that the time has come for policing to evolve from an occupation into a formal profession. Just as any other occupation that has advanced into a profession, provincial regulatory colleges of policing should be formed with the key objective of protecting the public from malpractice and malfeasance. A provincial college of policing would allow for (a) sustained and inclusive recruitment strategies, (b) foundational knowledge of the scholarship of policing, (c) evidence-based academy training, (d) mandatory ongoing (in-service) police education, and (e) expert, objective, community-focused, independent oversight. This proposal uses characteristics of the College of Policing in England and Wales as a guiding framework for the support and preparation of professionalizing policing in Canada.
\end{abstract}

Key Words Professionalization of police; professional college; college of policing; police reform; knowledge-based policing.

\section{INTRODUCTION}

Police professionalism and the professionalization of policing are two important and linked concepts, yet distinct in their definitions. Whereas police professionalism classically refers to the ways in which individual police officers carry out their duties, the professionalization of policing refers to the policing system. Notwithstanding that most police perform their duties professionally, the occupation of policing has yet to evolve into a formal profession (Blandford, 2017).

The developing nature of the professionalization of police continues to spark debate among both police practitioners and academics regarding its definition. This discourse is guided by contradictory understandings of what constitutes a profession and what is needed to sustain a professional police organization. On one hand, policing fits into definitions identifying professions as "structural, occupational and institutional arrangements for dealing with modern lives in risk societies" (Fyfe, 2013, p. 408). On the other hand, when evaluating formal definitions of a profession-being an occupation directed by a government registered body that establishes the scope of practice, minimum educational credential, continuing education requirement, and oversight process (Morris et al., 2006)_Canadian policing falls short.
Former structures of policing, particularly in the 1970s and 1980s, required little engagement with the public. Separation between the police and the public was normalized, as it was an era in which the police "always knew best" (Fyfe, 2013 , p. 410). However, the rise of public concerns about police malpractice in recent decades exemplifies why division should be left in the past. An Angus Reid Institute (2020) study illustrated that while $74 \%$ of Canadians viewed their local police either favourably $(53 \%)$ or very favourably $(21 \%), \approx 35 \%$ of younger Canadians and $\approx 25 \%$ of Indigenous and visible minority Canadians viewed the police unfavourably or very unfavourably. With pressures to diversify and the current Indigenous strife occurring in Canada, policing needs to pay attention to these demographics.

\section{Mistrust of Police}

Scholars have recently noted a growing public mistrust of the police, resulting in new criticisms being levelled at law enforcement (Dowler \& Zawilski, 2007; Wortley \& OwusuBempah, 2009; Blaskovits et al., 2018; Bain et al., 2014). In response to negative perceptions, many police services are altering their mandates, goals, and priorities to better align with the public's needs. In spite of their special legal status, the police have faced challenges in the 21st century that

\footnotetext{
Correspondence to: Lauren Magdeline Mitchell, 63 Woodfield Dr SW, Calgary, AB T2W 3T3, Canada. E-mail: Imitc132@mtroyal.ca

To cite: Sundberg, K. W., Witt, C., Abela, G., \& Mitchell, L. M. (2021). Peeling the paradigm: Exploring the professionalization of policing in Canada. Journal of Community Safety and Well-Being, 6(4), 187-190. https://doi.org/10.35502/jcswb.227

@ Author(s) 2021. Open Access. This work is distributed under the Creative Commons BY-NC-ND license. For commercial re-use, please contact sales@sgpublishing.ca. ge PUBLISHING Published by SG Publishing Inc. CSKA Official publication of the Community Safety Knowledge Alliance.
} 
have undermined their authority in the eyes of the public (Robertson, 2012). Specific to Canada, concerns relating to allegations of discrimination, toxic workplace culture, lack of transparency, and criticism regarding police use of force stand as the key issues of concern resulting in public mistrust of the police (Wortley \& Owusu-Bempah, 2011; Rawski \& Workman-Stark, 2018). Moreover, dispossession and systemic racism facilitated through law enforcement have promoted an especially distrusting relationship between Indigenous communities and the police.

Establishing trust, legitimacy, and credibility in the institutions of civil society (including police services) is primarily achieved through objective, fair, accessible, and communityfocused regulation and external oversight. For centuries, the professionals responsible for leading and administering the foundational institutions of our civil society have been regulated by government-appointed, yet autonomous, professional colleges tasked with regulating and licencing professions, their key objective being to protect the public from malpractice and malfeasance.

To this point, a profession constitutes a "knowledge-based" occupation whose practitioners are tasked with developing and transforming "formal knowledge" into specific functions intended to support evidence-based, standardized, and ethical practices (Freidson, 1994; Burrage \& Torstendahl, 1990). Sustained, comprehensive, and transferable "professionalism" can only be achieved once a diverse and expert foundation of knowledge specific to a profession has been learned, applied, and advanced by practitioners (De George, 1990; Larson, 1977; Richardson, 1988).

Peelian principles emphasizing the importance of public trust, crime prevention over law enforcement, and impartiality without favour have guided Canadian policing since its inception (Robertson, 2012). Although these principles continue to underlie the legitimacy of police in a democratic society, public expectations are fundamentally different from what they once were. In today's increasingly complex, interconnected, and diverse world, the ways public safety and security are achieved unquestionably have become significant societal issues brought to light by public discourse and debate.

It then becomes difficult to say, "the police are the public and the public are the police" (Lentz \& Chaires, 2007, p. 73) when the public questions the police's adherence to the rule of law. To address mounting public concerns, modern policing services should recruit and develop more educated, comprehensively trained, and socially diverse officers. Furthermore, policing as a whole requires attention and investment in (a) sustained, inclusive recruitment strategies; (b) foundational knowledge of the scholarship of policing; (c) evidence-based academy training; (d) mandatory ongoing (in-service) police education; and (e) expert, objective, community-focused, independent oversight.

\section{Conceptualization of Colleges of Policing}

While discourse surrounding the issue of professionalizing the police has been ongoing for decades (Sloane, 1954; Stone and Travis, 2011; Neyroud 2011; Robertson, 2012; Canadian Association of Chiefs of Police, 2012; Blandford, 2017; UK College of Policing, 2021), it was not until 2012, when the United Kingdom established its College of Policing, that a liberal democracy meaningfully embarked on the path towards professionalizing its policing services. Considering civilian policing first emerged in the United Kingdom when Sir Robert Peel established the Metropolitan Police of London in 1829-the model subsequently used to establish policing services in Canada, Australia, New Zealand, and across the Commonwealth-it is fitting the United Kingdom once again provides an example for democracies like Canada to follow when seeking to improve and advance policing.

There is little question that, over the past several decades, policing in Canada has become increasingly complex, dynamic, and technical-especially since the enactment of the Canadian Charter of Rights and Freedoms and resulting jurisprudence. The foundational skills and knowledge needed to practice policing effectively and competently are strikingly more advanced today than they were only a few decades ago. Police today must be critical thinkers who understand the diverse and complex nature of the communities they police. Moreover, they must have a temperament and empathy that supports the police as both law enforcement and civil service professionals.

Arguably, just as law, engineering, nursing, medicine, and other occupations evolved to include self-governing bodies that establish professional standards, foundational educational credentials, and a defined scope of practice for the profession, the time has come for policing to "formalize its professional framework" (Neyroud, 2011) through the establishment of Provincial Colleges of Policing. The central aim of these colleges would be to protect the public from professional malpractice and misconduct. Moreover, these colleges would also be tasked with advancing professional practice by supporting profession-specific research, scholarship, and learning. Lastly, professional organizations play a vital role in upholding professional practice by regulating the licencing of practitioners, as well as responding to complaints against licenced practitioners.

In most regards, the profession of policing has not deviated from its rigid and historic paramilitary roots. While many police services have successfully created ad hoc training regimes for their officers, evidence-based or peer-reviewed methods remain a rarity in Canada. It is our view that colleges of policing can stand as central institutions for increasing public trust and confidence in the police. Central to our view is having provincial governments establish professional colleges of police based on the following core principles:

Trust and Legitimacy in Policing. To achieve public trust and legitimacy, police policies, processes, and practices must be grounded on the Peelian principles of accountability, fairness, honesty, integrity, leadership, objectivity, openness, respect, and selflessness.

Evidence-Based Policing. Evidence must form the basis of all police policies, processes, and practices, with education, research, and scholarship being foundational and sustained elements of all police services.

- Democratic Policing. The fundamental protections offered by the Canadian Charter of Rights and Freedoms must form the basis upon which all police decision-making and practice occur. Open and democratic debate must be the genesis for all police policies, processes, and practices.

Standardized Policing. Standardized police policies, processes, and practices-including a uniform code of ethics, 
cognate officers trained and educated, and comparable approaches to patrol and investigative services-must be consistently applied by every officer, at every rank, in every police agency across the province.

- Accountable Policing. An independent, transparent, responsive, capably staffed, adeptly appointed, and wellequipped police oversight and investigative body must be a central element for all police activities in the province. This body-proposed as a significant part of the College of Policing and entirely separate from any other police agency-will protect the public from police malpractice and misconduct and build community trust through transparency and accountability while also consolidating and streamlining the way complaints involving police officers are received, investigated, and addressed.

\section{DISCUSSION}

A key aspect of any provincial college of policing would be the creation and enforcement of a code of ethics for all police service employees (officers and others). Currently, police malfeasance is primarily defined by either a province's police acts and regulations or the Criminal Code. Notwithstanding that every province has laws, regulations, and institutions in place to address police discipline, as do the Royal Canadian Mounted Police (RCMP), an established body of research clearly shows police oversight in Canada fails to meet public expectations and needs (Kwon \& Wortley, 2020). Police oversight agencies exist in every Canadian province, yet the vast majority of those tasked with investigating allegations of police misconduct are themselves police. Civilian police oversight bodies were introduced to combat perceptions of propolice bias in the complaints process and reduce intimidation. However, past government screenings have uncovered complaints received by these agencies being sent back to police services for internal investigations (Kwon \& Wortley, 2020). Moreover, studies show the majority of police oversight bodies in Canada are underfunded, under-resourced, and lacking in meaningful authority to take corrective actions (Kwon \& Wortley, 2020; Helme, 2015).

Arguably, colleges of policing, similarly to most professional regulatory colleges, would establish a self-sufficient, sustainable, and trusted structure through which police legitimacy and credibility can be maximized. Under such a structure, policing would transition from being an occupation into a self-regulated, publicly accountable, standardized, and evidence-based profession. Police officers would become licensed to practice policing. The practice of policing would be clearly defined, and any practitioners who engage in activities outside the established scope of practice would risk having their licence revoked-in essence ending their ability to engage in the practice of policing. Moreover, complaints of malpractice or malfeasance would be received, reviewed, investigated, and adjudicated by the College. Within this process, investigations ideally would be completed by nonpolicing professionals (e.g., lawyers, former investigators who worked for other investigative agencies, retired judges, etc.) and adjudicated by an independent, professional, publicly accessible, and focused tribunal. By requiring all police to complete continuing professional education, and also by supporting research and scholarship specific to the practice of policing, the public would be assured all police remain current in the understanding of their professional obligations and expectations of their performance.

Lastly, concerns of toxic hyper-masculinity, sexual harassment, and discrimination, along with deep-seated nepotism within policing services stand as some of the most significant issues concerning Canadians. Most notably associated with the RCMP, yet also prevalent within most sizable police services, reports of male officers harassing their female colleagues "demonstrate that the culture of policing continues to be resistant to the acceptance of females" (Barker \& Tavcer, 2018, p. 283). Clearly, past endeavours to address toxic workplace cultures have fallen short, with little evidence that current efforts stand to be much more effective than past ones. A college of policing could allow for a new, provincial, culture to emerge-one grounded in excellence in professional practice and enforceable by peer review. To this end, a college of policing would not only professionalize policing, it would also establish a new, province-wide, and community-focused policing culture, ultimately resulting in heightened public confidence and trust.

\section{CONCLUSION}

We posit that the only way to effectively and meaningfully advance policing is to advance the paradigm of policing. As with other occupations that have evolved into professions (e.g., law, medicine, teaching, engineering, etc.), a self-regulating professional organization needs to be established that (a) defines the professionalscopeof practicefor the profession,(b)establishes the foundational educational credential to practice, (c) registers and licences those who are authorized to practice, (d) develops, supports, and advances a professional body of knowledge, (e) protects the public against professional misconduct or malpractice, and (f) ensures the ongoing legitimacy and credibility of the profession.

Provincial Colleges of Policing are not entities that can be quickly created. Although there are steps that can be taken in the short term, these bodies undoubtedly will take years to fully establish. Furthermore, attaining agreement on what a professional model of policing will look like remains elusive. In add ressing this issue, we recommend using the College of Policing in England and Wales as a foundational model for Canadian provinces. With nationally recognized qualifications and standards (Montgomery, 2019), the College has set an unparalleled precedent for the development of professionalization in policing.

It should be noted that, in Britain, when professionalization was introduced, there was initial resistance to the change. However, an understanding of the purpose of the College, paired with the legitimacy and trust it built within police organizations and the public, allayed fears of change. There is no doubt the same may occur in Canadian provinces. Nevertheless, change needs to occur to enshrine trust and legitimacy within this profession.

The British Model relies on what they have labelled the Police Education Qualities Framework (College of Policing, 2017). The legitimacy of this framework is founded in the recognition that although police officers hold a tremendous amount of autonomy, they must also have the requisite knowledge, both theoretical and applied, to perform their duties 
ethically and efficiently. It is authorized by statute that every police service employee in England and Wales is provided with the skills necessary to prevent crime, protect the public, and secure public trust (Neyroud, 2011).

For years, police leaders have talked about the concept of professionalization, but very few have taken the time to put on paper what that may actually look like. Often, leading change requires a crisis, and policing in North America is in crisis. When public confidence in the police diminishes, the efficiency of the criminal justice system as a whole becomes harder to maintain. In Canada, we have not seen the same multitude of complex issues, riots, and social changes that are occurring in the United States. However, we know enough to understand they are closer than we think. As academics, pracademics, and police leaders, we understand this important discussion needed to commence. Whether the outcomes of this proposal are accepted remains to be seen. What we do know is that police leadership needs to occur now. This proposal is one step in that direction.

\section{ACKNOWLEDGEMENTS}

Funding sponsors had no role in the design of the study, in the collection, analyses, or interpretation of data, in the writing of the manuscript, or in the decision to publish the results.

\section{CONFLICT OF INTEREST DISCLOSURES}

The authors declare that there are no conflicts of interest.

\section{AUTHOR AFFILIATIONS}

*Associate Professor, Department of Economics, Justice, and Policy Studies, Mount Royal University, Calgary, AB, Canada; ${ }^{\dagger}$ Detective \& Lecturer, Calgary Police Service \& Department of Economics, Justice, and Policy Studies, Mount Royal University, Calgary, AB, Canada; ${ }^{\ddagger}$ Chief of Police, Taber Police Service, Taber, AB, Canada; IDepartment of Economics, Justice, and Policy Studies, Mount Royal University, Calgary, AB, Canada.

\section{REFERENCES}

Angus Reid Institute. (2020). Policing in Canada: Major study reveals four mindsets driving current opinions and future policy preferences. Retrieved from http://angusreid.org/policing-perspectivescanada-rcmp/

Bain, A., Robinson, B. K., \& Conser J. (2014). Perceptions of policing: Improving communication in local communities. International Journal of Police Science \& Management, 16(4), 267-276. https://doi.org/ 10.1350/ijps.2014.16.4.345

Barker, J., \& Tavcer, S. (2018). Women and their criminal justice system: A Canadian perspective (2nd ed.). Emond.

Blandford, S. (2017). The shift to professionalization of policing. Retrieved from https://online.wlu.ca/news/2017/10/18/shiftprofessionalization-policing

Blaskovits, B., Bennell, C., Huey, L., Kalyal, H., Walker, T., \& Javala, S. (2018). A Canadian replication of Telep and Lum's (2014) examination of police officers' receptivity to empirical research. Policing and Society, 30(3), 276-294. https://doi.org/10.1080/10439 463.2018 .1522315

Burrage, M., \& Torstendahl, R. (Eds), (1990). Professions in theory and history: Rethinking the study of the professions. Sage.

Canadian Association of Chiefs of Police. (2012). Speaking notes at the Canadian Association of Chiefs of Police 2012 Annual Conference. Retrieved from https://www. publicsafety.gc.ca/cnt/nws/ spchs/2012/20120822-en.aspx
College of Policing. (2017). Policing Education Qualifications Framework (PEQF). https://www.college.police.uk/What-wedo/Learning/ Policing-EducationQualifications-Framework/Pages/Policing Education-Qualifications-Framework.aspx

De George, R. T. (1990). Business ethics (3rd ed.). MacMillan.

Dowler, K., \& Zawilski, V. (2007). Public perceptions of police misconduct and discrimination: Examining the impact of media consumption. Journal of criminal justice, 35(2), 193-203. https://doi.org/10.1016/ i.jcrimjus.2007.01.006

Freidson, E. (1994). Professionalism reborn: Theory, prophecy and police. Polity Press.

Fyfe, N. R. (2013). Complex transition and uncertain trajectories: Reflections on recent developments in police professionalism. Journal of Workplace Learning, 25(6), 407-420. https://doi.org/10.1108/ JWL-08-2012-0059

Helme, R. (2015). Civilian oversight of police: The Canadian experience. Juridical Current, 18(1), 13-18.

Kwon, J., \&Wortley, S. (2020). Policing the police: Public perceptions of civilian oversight in Canada. Race and Justice, 25. https://doi.org/10.1177/ 2153368720924560

Larson, M. S. (1977). The rise of professionalism. University of California Press.

Lentz, S. A., \& Chaires, R. H. (2007). The invention of Peel's principles: A study of policing "textbook" history. Journal of Criminal Justice 35(1), 69-79. https://doi.org/10.1016/i.jcrimjus.2006.11.016

Montgomery, R. (2019). The role of the Canadian Association of Chiefs of Police in supporting the professionalization of police in Canada. Policing: A Journal of Policy and Practice, 15(1), 222-233. https:// doi.org/10.1093/police/pay105

Morris, P. W. G., Crawford, L., Hodgson, D., Shepherd, M. M., \& Thomas, J. (2006). Exploring the role of formal bodies of knowledge in defining a profession - The case of project management. International Journal of Project Management 24(8), 710-721. https://doi.org/10.1016/ j.ijproman.2006.09.012

Neyroud, P. W. (2011). Leading policing in the 21st Century: Leadership, democracy, deficits and the new professionalism. Public Money and Management, 37151, 347-354. https://doi.org/10.1080/09540 962.2011 .598346

Rawski, S. L., \& Workman-Stark, A. L. (2018). Masculinity contest cultures in policing organizations and recommendations for training interventions. Journal of Social Issues, 74(3), 607-627. https://doi.org/10.1111/ josi. 12286

Richardson, A. J. (1988). Accounting knowledge and professional privilege. Accounting, Organizations and Society, 13(4), 381-396.

Robertson, N. (2012). Policing: Fundamental principles in a Canadian context. Canadian Public Administration, 55(3), 343-363. https:// doi.org/10.1111/i.1754-7121.2012.00227.x

Sloane, C. F. (1954). Police professionalization. Journal of Criminal Law and Criminology, 45, 77.

Stone, C., \& Travis, C. (2011). Towards a new professionalism in policing. National Institute of Justice.

UK College of Policing. (2021). Policing guidance. Retrieved from https:// www.college.police.uk/

Wortley, S., \& Owusu-Bempah, A. (2011). Crime and justice: The experiences of black Canadians. In B. Perry (Ed.), Diversity, crime and justice in Canada (pp. 127-150). Oxford University Press.

Wortley, S., \& Owusu-Bempah, A. (2009). Unequal before the law: Immigrant and racial minority perceptions of the Canadian criminal justice system. Journal of International Migration and Integration/Revue de l'intégration et de la migration internationale, 10(4), 447-473. https://doi.org/10.1007/s12134-009-0108-x 